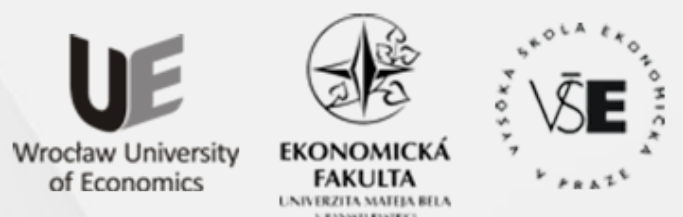

Conference Proceedings

Full TeXT PAPERS

edited by

Zofia Rusnak and Beata Zmyślona

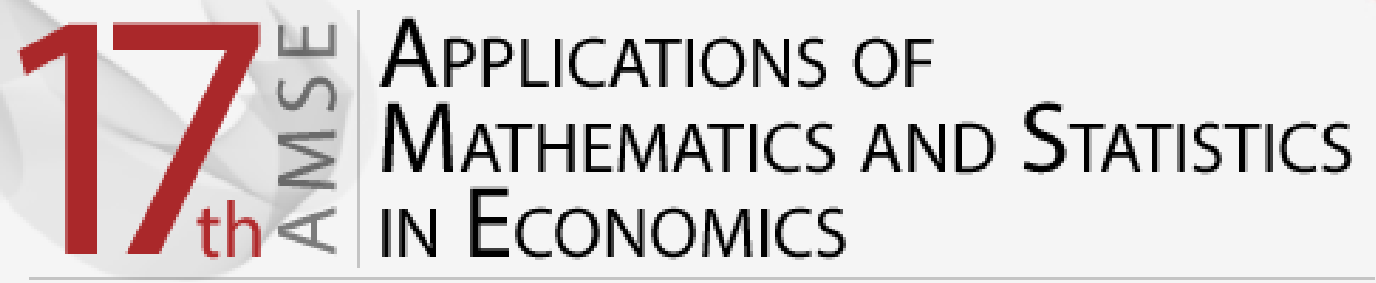

International Scientific Conference | Poland • 27-31 August 2014 
Scientific Committee

Richard Hindls, Stanislava Hronová, Rudolf Zimka, Walenty Ostasiewicz, Emília Zimková, Zofia Rusnak, Martin Bod'a

Organizing Committee

Beata Zmyślona, Cyprian Kozyra, Grzegorz Rogoziński, Kristýna Vltavská

\section{Reviewers}

Milan Bašta, Diana Bílková, Martin Bod'a, Joanna Dębicka, Tomáš Fiala, Jakub Fischer, Stanisław Heilpern, Karel Helman, Lenka Hudrlíková, Miroslav Hužvár, Nikola Kaspř́ková, Alena Kaščáková, Kamil Kladívko, Jindřich Klůfa, Pavol Král', Katarzyna Kuziak, Jana Langhamrová, Ivana Malá, Tomáš Marcinko, Luboš Marek, Miloš Maryška, Petr Mazouch, Zofia Mielecka-Kubień, Witold Miszczak, Petr Musil, Gabriela Nedelová, Walenty Ostasiewicz, Iva Pecáková, Viera Roháčová, Zofia Rusnak, Mária Stachová, Jana Špirková, Šárka Šustová, Jana Tepperová, Vladimír Úradníček, Kristýna Vltavská, Michal Vrabec, Dariusz Wawrzyniak, Henryk Zawadzki, Jaroslav Zbranek, Tomáš Zeithamer, Martin Zelený, Jan Zeman, Rudolf Zimka, Emília Zimková, Pavel Zimmermann, David Žižka

Layout

Martin Bod'a, Beata Zmyślona, Grzegorz Rogoziński

Front page design

Grzegorz Rogoziński

CD cover design

Beata Dębska

Articles published in the form submitted by the authors

All rights reserved. No part of this book may be reproduced in any form or in any means without the prior permission in writing of the Publisher

(C) Copyright by Wrocław University of Economics Wrocław 2014

ISBN 978-83-7695-421-9

Wydawnictwo Uniwersytetu Ekonomicznego we Wrocławiu

53-345 Wrocław, ul. Komandorska 118/120 www.ue.wroc.pl

Sprzedaż książek tel./fax 71 36-80-602

e-mail: econbook@ue.wroc.pl www.ksiegarnia.ue.wroc.pl 


\section{Contents}

Foreword

Diana Bílková: TL-Moments: Analogy of Classical L-Moments

Dagmar Blatná: Application of Robust Regression in the Analysis of Internet Access in European Countries

Martin Bod’a, Mária Kanderová: Rebalancing Issues in Tracking Error Variance Minimization

Martin Bod'a, Viera Roháčová: Application of Six Sigma Ideas to Timing Decisions at Financial Markets

Anton Dekrét, Rudolf Zimka: On the Price Hartwick's Task and Its Inverse in a Dynamic Model of an Economy with Exhaustible Resources

Joanna Dębicka, Agnieszka Marciniuk: Comparison of Reverse Annuity Contract and Reverse Mortgage on the Polish Market.

Petra Dotlačilová, Jitka Langhamrová: The Influence of Mortality Models for the Expected Future Life-time of Older People

Marek Ďurica, Lucia Švábová: Delta and Gamma for Chooser Options.

Vlastimil Farkašovský: New Concept of Pension Funds Performance Evaluation

Albert Gardon: The Normality of Weekly Relative Changes of the Freight Rate in Container Shipping.

Mária Grausová, Miroslav Hužvár, Jana Štrangfeldová: Healthcare Systems Efficiency in the Visegrád Group.

Stanisław Heilpern: Multiple Life Insurance - Pension Calculation

Alena Kaščáková, Gabriela Nedelová: Changes in Slovak Households' Economy

Igor Kollár, Pavol Král', Peter Laco: Methodology for Assessing Website Improvement in Corporate Environment.

Maciej Kostrzewski: Some Method of Detecting the Jump Clustering Phenomenon in Financial Time Series.

Cyprian Kozyra, Beata Zmyślona, Katarzyna Madziarska: Complementary Objective and Subjective Measures of Hospital Services Quality...

Pavol Král', Mária Stachová, Lukáš Sobíšek: Utilization of Repeatedly Measured Financial Ratios in Corporate Financial Distress Prediction in Slovakia

Ivana Malá: The Use of Finite Mixture Model for Describing Differences in Unemployment Duration

Lukáš Malec: Studying Economics and Tourism Industry Relations by Smooth Partial Least Squares Method Depending on Parameter. 
Tomáš Marcinko: Consequences of Assumption Violations Regarding Classical Location Tests.

Edyta Mazurek: The Income Tax Progression Depending on Social Insurance Contribution in Poland.

Petr Musil, Jana Kramulová, Jan Zeman: Regional Consumption Expenditures: An Important Starting Point for Regional Input-output Tables.

Katarzyna Ostasiewicz, Walenty Ostasiewicz: Good Life: From Political to Human Economy

Anna Sączewska-Piotrowska: Analysis of Poverty Transitions in Poland Using Multilevel Discrete-Time Event History Models

Martina Šimková, Petra Švarcová: Disadvantaged University Students in the Czech Republic.

Michal Široký: The Use of Short-term Business Statistics for Quarterly GDP Flash Estimates in the Czech Republic

Zdeněk Šulc, Hana Řezanková: Evaluation of Recent Similarity Measures for Categorical Data.

Lucia Švábová, Marek Ďurica: The Relationship Between the Finite Difference Method and Trinomial Trees

Kristýna Vltavská, Jaroslav Sixta: The Estimation of Final Consumption Expenditures

Lenka Vraná: Business Cycle Analysis: Tracking Turning Points

Janusz Wywiał: On Bayesian Testing in Auditing

Emília Zimková: Window Analysis of Supper-efficiency Change: Case of the Slovak Banking System ....

Beata Zmyślona: Statistical Modelling of the Impact of Diabetes on the Risk of Hospitalization 


\title{
THE USE OF SHORT-TERM BUSINESS STATISTICS FOR QUARTERLY GDP FLASH ESTIMATES IN THE CZECH REPUBLIC
}

\author{
MICHAL ŠIROKÝ \\ University of Economics, Prague, Faculty of Informatics and Statistics, Department of Economic \\ Statistics, W. Churchill Sq. 4, 13067 Prague 3, Czech Republic \\ email: michal.siroky@czso.cz
}

\begin{abstract}
Quarterly GDP estimates belong to the most important macroeconomic indicators. Their first releases, sometimes called flash estimates, are available in most European countries 45 days after the end of the respective quarter. Because more timely information is required by policy makers, Eurostat has the intention of shortening the publication delay to 30 days. Due to the fact that the traditional approach to GDP estimates compilation in the Czech Republic does not allow to meet this requirement, it is necessary to develop a new methodology for such estimates. The paper focuses on the most important part of GDP, which is represented by gross value added in sectors of non-financial corporations and households. Results of shortterm business statistics are available sufficiently timely and therefore they could serve as a proxy for gross value added. Monthly statistical surveys in industry, construction and selected branches of market services are used in the analysis. Methodological approach is based on the co-integration principles, which lead to the Error Correction Model. The goal of the paper is to present experimental flash estimates of gross value added for all quarters of 2013 and their comparison with subsequently released traditional estimates.
\end{abstract}

Key words: gross domestic product, flash estimate, co-integration, error correction model.

DOI: $10.15611 /$ amse.2014.17.26

\section{Introduction}

Early availability of key macroeconomic indicators is required by many users of statistical data. For this reason, flash estimates of gross domestic product (GDP) are nowadays published by most of national statistical institutes (NSIs) in the European Union (EU). In Eurostat (1999), a flash estimate is defined as "the earliest picture of the economy according to national accounts concepts, which is produced and published as soon as possible after the end of the quarter, using a more incomplete set of information than the set used for traditional quarterly accounts". While the NSIs are requested to transmit the traditional GDP estimates to Eurostat at 70 days after the end of the quarter, the flash estimates are usually published after 45 days. Although coverage of the flash estimates is often limited to the growth rate of total GDP at constant prices, it is very important to compile these estimates in detailed structure according to the production and expenditure side, in order to achieve sufficient accuracy of the results. Because the flash estimates are based on less information than the traditional ones, they usually rely more on statistical and econometric methods and various assumptions.

The Czech Statistical Office has started producing the GDP flash estimates in 2008. The respective news release, published at 45 days after the end of the quarter, comprises only development of the total GDP at constant prices. In general the flash estimates in the Czech 
Republic are compiled using the same methodology as the traditional ones. Most aggregates are based on a preliminary processing of respective data sources. The production and expenditure method of calculation is applied. Because data sources used for the production approach are considered to be more reliable than ones used for the expenditure approach, the total GDP at current prices is derived from the production side, i.e. as the sum of gross value added (GVA) and net taxes on products. On the contrary, price indices used for recalculation to constant prices are more suitable for expenditure components. This is why the total GDP deflator is derived from the expenditure side.

In the last year Eurostat conceived an intention to shorten publication delays of the flash estimates of the EU to 30 days. Several are the reasons: more timely information is requested by policy makers (mainly the European Central Bank) and the need of an efficient early warning system has been exacerbated by the recent economic crisis. Moreover, it would align the European calendar to that of the United States, where the first GDP estimates are released at 30 days. Because the GDP figures for the EU are calculated using the so-called "direct method", i.e. by aggregation of data from the member states, it would be necessary to compile these estimates at the level of individual member states.

In case of the Czech Republic, it would not be possible to apply the current methodology at 30 days due to unavailability of many data sources. The main source for the estimation of GVA is represented by the quarterly enterprise survey. Its results are available around 42 days after the end of the quarter and speeding up of the survey is not envisaged. Therefore it would be necessary to use alternative data sources for the flash estimates. Results of monthly shortterm business statistics (STS) are available sufficiently timely. They have been already used for experimental flash estimates in the Czech conditions (see Jilek and Vojta, 2001 and Jilek and Vojta, 2003). The monthly surveys are not fully coherent with the quarterly ones but it is supposed that the incoherency could be partly overcome using more advanced estimation methods. The aim of the paper is to assess suitability of STS for the GDP flash estimates at 30 days, using methodological approach based on the Error Correction Model.

\section{Data sources used in the analysis}

GVA in the sectors of non-financial corporations and households constitutes around $82 \%$ of the total GVA. It also has a decisive impact on development of the total GVA in time. For this reason, sufficiently accurate estimation of this item represents the key issue for the flash estimates. The paper focuses on two above mentioned sectors only. The methodology for the estimation of GVA in the other sectors will be elaborated later.

The main data source for traditional quarterly estimates of GVA in sectors of non-financial corporations and households is the quarterly enterprise survey in business units and entrepreneurs. It covers all branches of the economy except for financial intermediation. In most branches only units with 50 and more employees are surveyed. Estimates for smaller units are made using administrative data (mainly numbers of social insurance holders and sales from value added tax returns are concerned). The grossed-up results are calculated in the breakdown according to two-digit CZ-NACE classification (the Czech version of NACE Rev. 2 classification). The first processing is available approximately 42 days after the quarter.

GVA is calculated as a difference of output at basic prices and intermediate consumption at purchasers' prices. Output is calculated using the following indicators from the survey:

Sales of own goods

+ Sales of own services 
+ Change in in-house inventories of own production

+ Capitalization

+ Sales of goods for resale

- Costs of goods sold

Intermediate consumption is obtained from the indicator "Production consumption".

Monthly short-term business statistics is based on results of three statistical surveys, which comprise much less indicators than the quarterly survey:

- Monthly survey in industry covers sections B (Mining and quarrying), C (Manufacturing) and D (Electricity, gas, steam and air conditioning supply) of the CZ-NACE classification. The indicator "sales from industrial activity" could be used as an approximation of output. It represents sales of goods and services classified in the CZ-CPA 05-39, i.e. sales adjusted for secondary non-industrial activities of an enterprise. They are measured at current prices of the reference year. In most of industrial divisions, this indicator also serves as a basis for calculation of industrial production index.

- Monthly survey in construction covers activities under the section F (41 Construction of buildings, 42 - Civil engineering and 43 - Specialized construction activities) of the CZ-NACE classification. The indicator "construction work carried out by companies own workers" is used in the analysis. It represents the volume of construction work done by the unit's registered workers, including productive work of apprentices and volume of construction work on own tangible fixed assets.

- Most of services activities are covered by the monthly survey in trade and services. It provides information on development of sales in the CZ-NACE divisions 45 (wholesale and retail trade and repair of motor vehicles and motorcycles), 47 (retail trade, except of motor vehicles and motorcycles), sections $\mathrm{H}$ (transportation and storage), I (accommodation and food service activities), J (information and communication), L (real estate activities), M (professional, scientific and technical activities) without 72 and 75, and $\mathrm{N}$ (administrative and support service activities). In the survey, aggregate sales from the sale of own products, goods and services are observed. Sales are reported excluding VAT.

The population of the monthly surveys consists of units that are considered to be active, are classified in the aforementioned CZ-NACE activities and do their business in order to make profit (i.e. belong to the sector of non-financial corporations or to the households sector). The sample consists of the sample part and the exhaustive part. Not-surveyed units are estimated using administrative data sources similarly as in case of the quarterly survey. At the time of the flash estimate, a part of the monthly results will not be available yet. Concretely the third month of the quarter for construction and services is processed a few days later. It would be necessary to employ a forecasting technique or make an estimate using some alternative indicator (for example from the business tendency survey).

\section{Methodological approach}

The analysis is based on application of the autoregressive distributed lag (ADL) model. It is a type of regression model that includes lagged values of the dependent variable and current 
and lagged values of one or more explanatory variables. This approach has been popularized by Hendry and Mizon (1978). For purposes of the GDP flash estimates, it has been already applied in the Slovak conditions (see Haluska, 2011). Only the simplest case ADL(1,1) with one explanatory variable and one period lagged terms is considered here:

$$
Y_{t}=\alpha_{0}+\alpha_{1} Y_{t-1}+\gamma_{0} X_{t}+\gamma_{1} X_{t-1}+u_{t}
$$

where each value of $u_{t}$ has a mean of zero, a constant variance and is serially uncorrelated.

Time series studied in the paper are trended and therefore non-stationary (their mean and/or variance depend on time). The problem with non-stationary data is that the standard regression procedures can easily lead to incorrect conclusions. In these cases a very significant relationship can be found while the variables used in the analysis have no interrelationships. This is called a spurious regression (see for example Asteriou and Hall, 2011). Therefore it is necessary to test whether the variables are really related. In this case we say that the variables are cointegrated. It means that there is a genuine long-run equilibrium between variables, which takes the form:

$$
Y_{t}^{*}=\beta_{0}+\beta_{1} X_{t}^{*}
$$

When the variables are cointegrated, it is convenient to express the $\operatorname{ADL}(1,1)$ model in an equivalent re-parametrized form which is called the error-correction model (ECM):

$$
\Delta Y_{t}=\gamma_{0} \Delta X_{t}-\pi\left(Y_{t-1}-\beta_{0}-\beta_{1} X_{t-1}\right)+u_{t}
$$

This form has the advantage of including both long-run and short-run information. This is because the long-run equilibrium $Y_{t-1}-\beta_{0}-\beta_{1} X_{t-1}$ is included in the model together with the short-run dynamics captured by the differenced term. In this model, $\gamma_{0}$ measures the short-run effect that a change in $X_{t}$ will have on a change in $Y_{t}$. On the other hand, $\pi=1-\alpha_{1}$ is the feedback effect and shows how much of the disequilibrium is being corrected, i.e. the extent to which any disequilibrium in the previous period affects any adjustment in $Y_{t}$. It provides us with information about the speed of adjustment in cases of disequilibrium. $\beta_{1}=\left(\gamma_{0}+\gamma_{1}\right) /(1-$ $\alpha_{1}$ ) is the long-run multiplier. If the variables are in $\operatorname{logs}$ then $\beta_{1}$ is the long-run elasticity of $Y$ with respect to $X$.

A convenient way to estimate the ECM was introduced in Engle and Granger (1987), involving four steps (for a detailed description see Arlt, 1997).

Step 1: Testing the variables for their order of integration

By definition, cointegration necessitates that the variables are integrated of the same order. (Integration of order $d$ means that the series after differentiating $d$ times becomes stationary.) Thus the first step is to test each variable to determine its order of integration. The augmented Dickey-Fuller (ADF) test is the most frequently used. Other suitable tests are for example the Phillips-Peron test and the KPSS test. If all variables are integrated of the same order then we proceed with step two. 
Step 2: Estimation of the long-run relationship

If the results of step 1 indicate that all variables are integrated of the same order, the next step is to estimate the long-run equilibrium relationship and obtain the residuals of this equation. Adequacy of the model should be checked with the help of a test for serial correlation of residuals (e.g. Durbin-Watson test, Breusch-Godfrey test) and a test for heteroscedasticity of residuals (e.g. White test).

Step 3: Checking for the order of integration of the residuals

In order to determine if the variables are actually cointegrated, it is necessary to test if the estimated residuals from the long-run relationship are stationary. Then the variables are cointegrated. It can be done by performing the ADF test (or another stationarity test) on the residual series. The critical values differ from the standard ADF values, being more negative. If we find that the residuals are stationary then we can reject the hypothesis that the variables are not cointegrated.

Step 4: Estimation of the error-correction model

If the variables are cointegrated, the residuals from the equilibrium regression can be used to estimate the error-correction model and to analyze the long-run and short-run effects of the variables as well as to see the adjustment coefficient, which is the coefficient of the lagged residual terms of the long-run relationship identified in step 2. At the end we always have to check for the adequacy of the model by performing diagnostic tests for serial correlation and heteroscedasticity of residuals.

\section{Results of experimental calculations}

GVA is defined as a difference of output and intermediate consumption. Therefore both aggregates need to be estimated. Indicators from STS are closely related to output. Monthly surveys provide no information about intermediate consumption. For this reason, the indicators were used for modelling of output only. Because shares of intermediate consumption to output are relatively stable, the estimates of intermediate consumption were obtained using one-period-ahead forecasts of these shares. The ARIMA models with seasonal component were applied for this task. Pure forecasting with the ARIMA models was also used to obtain the estimates of output for branches not covered by STS (e.g. agriculture).

The models for the output estimation were built in line with the approach described in the previous section. The calculations were carried out in the breakdown into two-digit NACE Rev. 2. In total, 56 single-equation models were estimated ( 25 for industry, 3 for construction and 28 for services). In each model, output represented the dependent variable and appropriate indicator from STS represented the independent variable. Usually the model included also dummy variables - linear trend and/or seasonal variables. In all cases, four different specifications were compared:

- Time span from 1Q 2002, ECM with quarterly log differences

- Time span from 1Q 2002, ECM with annual log differences

- Time span from 1Q 2008, ECM with quarterly log differences

- Time span from 1Q 2008, ECM with annual log differences

Comparable time series from the quarterly enterprise survey exist from 1Q 2002. Nevertheless, the figures for the period 2002-2007 are available only in the breakdown into 
NACE Rev. 1.1. For the purpose of this analysis, they were converted into NACE Rev. 2 using appropriate conversion matrices.

As an example, the model for the important branch NACE 29 (Manufacture of motor vehicles, trailers and semi-trailers) is presented here.

Estimation of the long-run relationship:

$$
\log (\text { OUTPUT29) }=-0.0195+0.9797 * \log (\text { SALES29 })
$$

$\mathrm{R}^{2}=0.9941, \mathrm{~s}(\mathrm{e})=0.0133$

$$
(-6.7) \quad(59.4)
$$

(t-statistics in parentheses)

Estimation of the error-correction model:

$$
\begin{aligned}
& \quad \Delta_{4} \log (\text { OUTPUT29 })=-1.1912 * R^{2} \text { SID }_{t-4}+1.0070 * \Delta_{4} \log (\text { SALES29) } \\
& \mathrm{R}^{2}=0.9940, \mathrm{~s}(\mathrm{e})=0.0110 \\
& (\mathrm{t} \text {-statistics in parentheses })
\end{aligned}
$$

Different specifications of the models were evaluated using criteria stated in the previous section. However, the emphasis was put on the accuracy of the estimated growth rates. For this purpose, mean absolute differences of real and estimated growth rates for the period from 1Q 2009 to 4Q 2012 were computed for each branch and a model specification.

Table 1. Mean absolute differences of real and estimated growth rates of output in percentage points ( $\Delta_{1}$ is a model with quarterly $\log$ differences; $\Delta_{4}$ is a model with annual log differences)

\begin{tabular}{c|l|c|cccc}
\hline \multirow{2}{*}{ Code } & \multicolumn{2}{|c|}{ Name (shortened) } & \% share & \multicolumn{2}{c}{ Span from 2002} & \multicolumn{2}{c}{ Span from 2008 } \\
\cline { 3 - 6 } & & on total & $\Delta_{1}$ & $\Delta_{4}$ & $\Delta_{1}$ & $\Delta_{4}$ \\
\hline 05 & Mining of coal and lignite & 0.71 & 3.92 & 4.13 & 2.88 & 3.07 \\
08 & Other mining and quarrying & 0.18 & 3.64 & 5.12 & 2.86 & 1.89 \\
10 & Manufacture of food products & 2.91 & 1.85 & 1.83 & 1.28 & 1.27 \\
11 & Manufacture of beverages & 0.72 & 3.96 & 2.85 & 1.62 & 1.55 \\
13 & Manufacture of textiles & 0.53 & 1.96 & 2.11 & 1.53 & 1.72 \\
15 & Manufacture of leather & 0.06 & 7.02 & 8.27 & 6.18 & 6.57 \\
16 & Manufacture of wood & 0.94 & 3.43 & 3.48 & 3.61 & 2.98 \\
17 & Manufacture of paper products & 0.70 & 2.12 & 1.95 & 1.60 & 1.20 \\
18 & Printing and reproduction & 0.44 & 3.57 & 3.55 & 2.12 & 2.25 \\
19 & Manufacture of coke and petrol. & 1.67 & 2.50 & 3.04 & 0.81 & 0.92 \\
20 & Manufacture of chemicals & 2.14 & 3.33 & 5.23 & 2.17 & 3.18 \\
21 & Manufacture of pharm. products & 0.39 & 6.06 & 4.78 & 2.93 & 3.32 \\
22 & Manufacture of plastic products & 2.80 & 2.40 & 2.00 & 2.18 & 1.86 \\
23 & Manufacture of non-metallic prod. & 1.42 & 3.17 & 2.78 & 3.01 & 2.66 \\
24 & Manufacture of basic metals & 2.29 & 3.03 & 3.42 & 2.05 & 2.71 \\
25 & Manufacture of metal products & 3.52 & 2.12 & 2.27 & 0.96 & 1.09 \\
\hline
\end{tabular}




\section{$12 \backsim$ APPLICATIONS OF \\ Mathematics and Statistics \\ IN ECONOMICS}

International Scientific Conference | Poland • 27-31 August 2014

Table 1. (Continued)

\begin{tabular}{|c|c|c|c|c|c|c|}
\hline \multirow{2}{*}{ Code } & \multirow{2}{*}{ Name (shortened) } & \multirow{2}{*}{$\begin{array}{l}\% \text { share } \\
\text { on total }\end{array}$} & \multicolumn{2}{|c|}{ Span from 2002} & \multicolumn{2}{|c|}{ Span from 2008} \\
\hline & & & $\Delta_{1}$ & $\Delta_{4}$ & $\Delta_{1}$ & $\Delta_{4}$ \\
\hline 26 & Manufacture of electronic prod. & 2.82 & 1.73 & 1.96 & 1.71 & 1.68 \\
\hline 27 & Manufacture of electrical equip. & 2.87 & 2.57 & 2.69 & 1.98 & 1.92 \\
\hline 28 & Manufacture of machinery n.e.c. & 3.36 & 1.87 & 1.51 & 1.07 & 0.98 \\
\hline 29 & Manufacture of motor vehicles & 9.56 & 1.45 & 1.72 & 1.00 & 0.94 \\
\hline 30 & Manufacture of other transport & 0.64 & 4.63 & 4.72 & 3.51 & 3.26 \\
\hline 31 & Manufacture of furniture & 0.38 & 2.73 & 2.33 & 2.63 & 2.12 \\
\hline 32 & Other manufacturing & 0.59 & 3.31 & 2.58 & 2.20 & 2.13 \\
\hline 33 & Repair and installation & 1.09 & 5.71 & 9.18 & 4.71 & 4.89 \\
\hline 35 & Electricity, gas, steam supply & 12.45 & 8.06 & 7.38 & 6.01 & 5.38 \\
\hline 41 & Construction of buildings & 2.87 & 3.41 & 3.56 & 2.86 & 2.21 \\
\hline 42 & Civil engineering & 2.41 & 5.21 & 3.95 & 3.98 & 3.64 \\
\hline 43 & Specialized construction activities & 2.71 & 3.04 & 4.90 & 2.99 & 3.87 \\
\hline 45 & Trade of motor vehicles & 1.04 & 2.63 & 3.43 & 2.63 & 1.70 \\
\hline 47 & Retail trade, except of vehicles & 3.04 & 2.85 & 3.59 & 2.25 & 2.48 \\
\hline 49 & Land transport & 3.10 & 1.75 & 2.33 & 1.28 & 1.05 \\
\hline 50 & Water transport & 0.01 & 4.52 & 5.49 & 2.46 & 3.01 \\
\hline 51 & Air transport & 0.38 & 1.12 & 1.88 & 1.15 & 0.99 \\
\hline 52 & Warehousing & 1.55 & 2.28 & 3.68 & 1.83 & 2.56 \\
\hline 53 & Postal and courier a & 0.37 & 1.33 & 1.27 & 0.67 & 0.93 \\
\hline 55 & Accommodation & 0.43 & 3.44 & 3.43 & 1.69 & 1.43 \\
\hline 56 & Food and beverage service & 0.94 & 3.12 & 3.11 & 1.96 & 2.00 \\
\hline 58 & Publishing activities & 0.36 & 2.43 & 3.44 & 1.81 & 1.65 \\
\hline 59 & Motion picture, video production & 0.17 & 4.82 & 5.20 & 4.39 & 3.12 \\
\hline 60 & Programming and broadcasting & 0.26 & 3.64 & 3.05 & 1.68 & 1.18 \\
\hline 61 & Telecommunications & 1.33 & 1.12 & 1.08 & 0.75 & 0.69 \\
\hline 62 & Computer programming & 1.60 & 2.13 & 2.61 & 1.76 & 1.55 \\
\hline 63 & Information service activities & 0.27 & 3.99 & 3.21 & 2.19 & 2.05 \\
\hline 68 & Real estate activities & 2.06 & 2.66 & 2.84 & 1.98 & 1.77 \\
\hline 69 & Legal and accounting activities & 0.84 & 3.11 & 2.16 & 3.42 & 2.48 \\
\hline 70 & Activities of head offices & 0.63 & 11.40 & 6.92 & 7.17 & 4.59 \\
\hline 71 & Architectural and engin. activities & 1.70 & 4.32 & 3.79 & 3.20 & 3.56 \\
\hline 73 & Advertising and market research & 0.98 & 2.02 & 2.29 & 1.64 & 1.42 \\
\hline 74 & Other professional activities & 0.56 & 7.49 & 8.29 & 5.91 & 4.84 \\
\hline 77 & Rental and leasing activities & 0.28 & 3.63 & 4.75 & 3.87 & 3.57 \\
\hline 78 & Employment activities & 0.29 & 4.74 & 3.60 & 1.22 & 1.73 \\
\hline 79 & Travel agencies & 0.55 & 8.59 & 6.66 & 3.38 & 3.78 \\
\hline 80 & Security activities & 0.22 & 2.91 & 3.05 & 2.28 & 2.71 \\
\hline 81 & Services to buildings & 0.38 & 2.53 & 2.93 & 2.67 & 2.19 \\
\hline 82 & Office administrative & 0.40 & 3.14 & 4.49 & 2.27 & 3.06 \\
\hline 96 & Other personal service activities & 0.19 & 4.78 & 4.35 & 4.00 & 2.58 \\
\hline
\end{tabular}

Source: Czech Statistical Office, own calculations. 


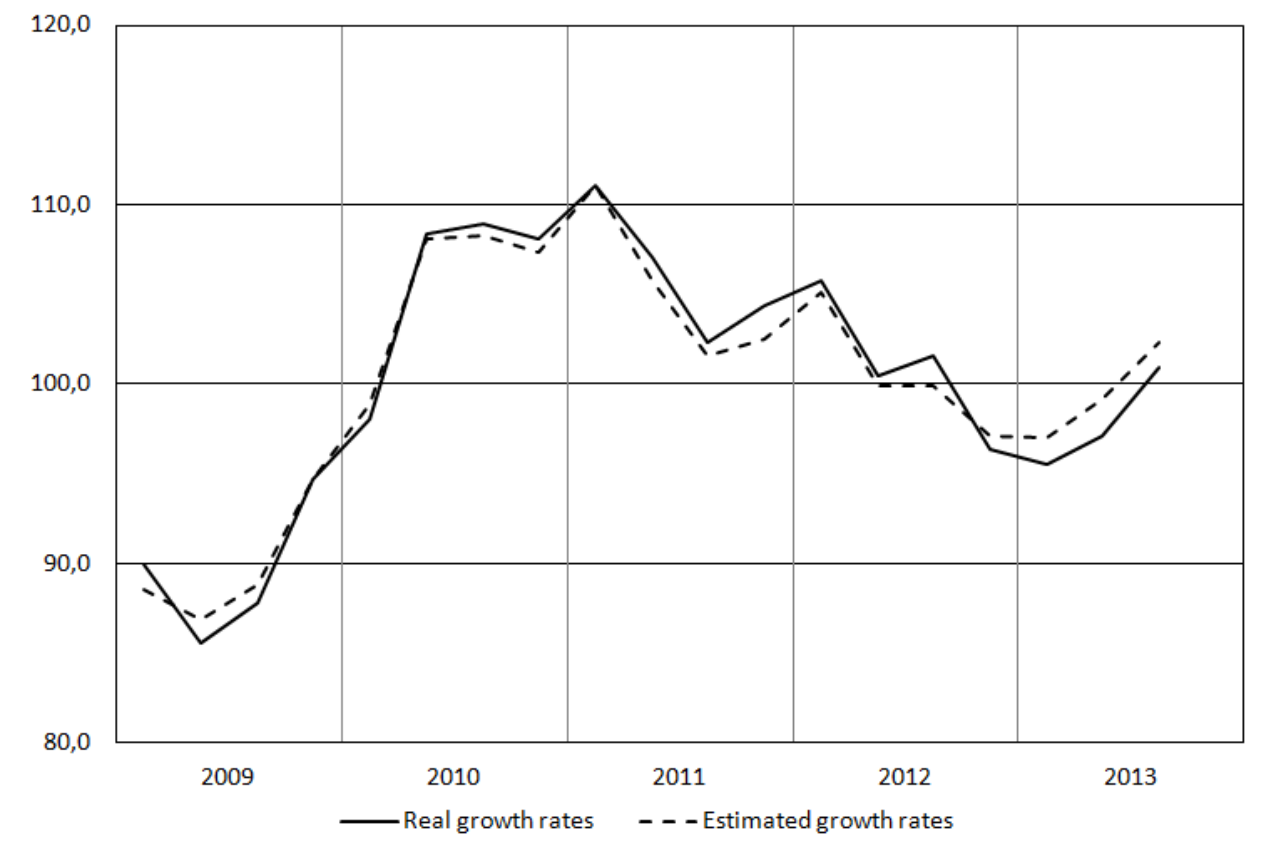

Figure 1. Real and estimated growth rates of total output (in \%) Source: Czech Statistical Office, own calculations.

The predictive ability of the models was further evaluated using out-of-sample forecasts for the period 1Q 2013 - 4Q 2013. These quarters did not belong to the estimation period of the models. The forecasts were made under real conditions of each flash estimate compilation. It means that data vintages used for forecasting corresponded to those available at the time of each flash estimate compilation, without taking into account subsequent revisions of both dependent and independent variables. The obtained flash estimates were then compared with the real figures from the quarterly enterprise survey. As a matter of interest, a similar comparison was made for figures from the preliminary processing of the quarterly enterprise survey, which are used for the currently published flash estimates at 45 days after the quarter. It is thus possible to compare these two methods of a flash estimate compilation. However, only the method using STS could be applied at 30 days after the quarter.

The growth rates computed from the out-of-sample forecasts of total output and their comparison with real growth rates is included in the following table.

Table 2. Evaluation of out-of-sample forecasts of total output

\begin{tabular}{|c|c|c|c|c|c|}
\hline \multirow[b]{2}{*}{ Period } & \multirow[b]{2}{*}{$\begin{array}{l}\text { Real growth } \\
\text { rates in } \%\end{array}$} & \multicolumn{2}{|c|}{ Forecasted growth rates in $\%$} & \multicolumn{2}{|c|}{ Differences in p. p. } \\
\hline & & $\begin{array}{c}\text { ECM } \\
\text { with STS }\end{array}$ & $\begin{array}{l}\text { Prelim. proc. } \\
\text { of q. survey }\end{array}$ & $\begin{array}{c}\text { ECM } \\
\text { with STS }\end{array}$ & $\begin{array}{l}\text { Prelim. proc. } \\
\text { of q. survey }\end{array}$ \\
\hline & 1 & 2 & 3 & $4=2-1$ & $5=3-1$ \\
\hline 1Q 2013 & -3.81 & -4.01 & -4.87 & -0.20 & -1.06 \\
\hline 2Q 2013 & -2.23 & -2.10 & -2.48 & 0.13 & -0.25 \\
\hline 3Q 2013 & 1.50 & 1.15 & 0.52 & -0.35 & -0.98 \\
\hline 4Q 2013 & 3.05 & 3.84 & 2.12 & 0.79 & -0.93 \\
\hline
\end{tabular}

Source: Czech Statistical Office, own calculations. 
An analogous table is provided for gross value added. In case of the ECM, the ARIMA models were applied to obtain forecasts of the share of intermediate consumption to output.

Table 3. Evaluation of out-of-sample forecasts of total gross value added

\begin{tabular}{|c|c|c|c|c|c|}
\hline \multirow[b]{2}{*}{ Period } & \multirow[b]{2}{*}{$\begin{array}{l}\text { Real growth } \\
\text { rates in } \%\end{array}$} & \multicolumn{2}{|c|}{ Forecasted growth rates in $\%$} & \multicolumn{2}{|c|}{ Differences in p. p. } \\
\hline & & $\begin{array}{c}\text { ECM } \\
\text { with STS } \\
\end{array}$ & $\begin{array}{l}\text { Prelim. proc. } \\
\text { of q. survey }\end{array}$ & $\begin{array}{c}\text { ECM } \\
\text { with STS } \\
\end{array}$ & $\begin{array}{l}\text { Prelim. proc. } \\
\text { of q. survey }\end{array}$ \\
\hline & 1 & 2 & 3 & $4=2-1$ & $5=3-1$ \\
\hline 1Q 2013 & -5.44 & -4.46 & -6.43 & 0.98 & -0.99 \\
\hline 2Q 2013 & -0.82 & -1.00 & -0.71 & -0.18 & 0.11 \\
\hline 3Q 2013 & 3.00 & 1.87 & 1.94 & -1.13 & -1.06 \\
\hline 4Q 2013 & 3.78 & 2.37 & 2.41 & -1.41 & -1.37 \\
\hline
\end{tabular}

Source: Czech Statistical Office, own calculations.

\section{Conclusions}

According to experimental calculations, the ability of the STS indicators to anticipate later available results of the quarterly survey is very dependent on a particular branch. In general, better results were obtained for industry (with some exceptions like NACE 35) than for construction and market services. Although differences between real and estimated growth rates were sometimes significant at the level of two-digit divisions, relatively accurate estimates of the total output were obtained for all quarters of 2013. They were even better than estimates from preliminary processings of the quarterly survey, which are used for the currently published flash estimates. A different situation arises when estimates of gross value added are concerned. Due to unavailability of information on intermediate consumption in STS, the estimates of gross value added were of worse quality.

Further research will be devoted to looking for suitable indicators for branches not covered by STS (e.g. agriculture) and for the remaining institutional sectors (mainly the general government sector). Attention should be paid also to investigation of possible indicators for net taxes on products, which are necessary to obtain estimates of total GDP.

\section{References}

1. ARLT, J. 1997. Cointegration in one-equation models. In Politicka ekonomie, vol. 45, iss. 5, pp. 733-746.

2. ASTERIOU, D., HALL, S. G. 2011. Applied Econometrics (Second edition). Palgrave Macmillan. 2011. ISBN 978-0-230-27182-1

3. ENGLE, R. F., GRANGER, C. W. J. 1987. Co-integration and Error Correction: Representation, Estimation and Testing. In Econometrica, vol. 55, iss. 2, pp. 251-276.

4. EUROSTAT 1999. Handbook on Quarterly National Accounts. Luxembourg: Eurostat. 1999. ISBN 92-828-7259-9

5. HALUSKA, J. 2011. Consumption Function as an Instrument for Flash Estimates of Final Consumption of Households. In Ekonomicky casopis (Journal of Economics), 2011, vol. 59, iss. 4, pp. 337-354. 
6. HENDRY, D. F., MIZON, G. E. 1978. Serial correlation as a convenient simplification, not a nuisance: A comment on a study of the demand for money by the Bank of England. In Economic Journal, 1978, vol. 88, iss. 351, pp. 549-563.

7. JILEK, J., VOJTA, M. 2001. Users flash estimates of the gross domestic product shortterm changes of the Czech Republic. In Politicka ekonomie, vol. 49, iss. 1, pp. 74-90.

8. JILEK, J., VOJTA, M. 2003. Enhanced user flash estimates of quarter-on-quarter changes in gross domestic product of the Czech Republic at constant prices. In Politicka ekonomie, vol. 51, iss. 5, pp. 676-694. 